\title{
Delinquent Behavior Among Youthful Offenders. A Study On Community Service Order Program, Malaysia
}

\author{
S.A. Suhaimi ${ }^{1}$, A. Nasyrah ${ }^{2}$, M.S. Khairiyah ${ }^{3}$, A.A. Norazlin ${ }^{4}$ \\ Universiti Teknologi MARA, UiTM Negeri Sembilan, Kampus Seremban, Malaysia \\ suhaimi@uitm.edu.my ${ }^{1}$,nasyrah185@uitm.edu.my², khairiyah870@uitm.edu.my³
}

\begin{abstract}
The increase in cases of delinquent behavior of youths in Malaysia is an issue that should be given serious attention. Although statistics of the Department of Social Welfare showed the rate of decline in the case of youthful offenders from 2013 to 2018 , but the rate of decline is very slow and sometimes fluctuate which requires action policies and effective programs to address the issue affirmatively. Apart from looking at the actions and initiatives that should be taken by the government and the authorities in dealing with this issue, the identification of the main factors of the problem of an offence is also not to be underestimated. This article examines the main factors of the offences among youthful offenders in the Community Service Order Program under the Department of Social Welfare. On the other part, this paper also investigates the relationship between the delinquent behavior and the participation of respondents in the National Service Training Programme (PLKN). A total of 79 trainees under Community Service Order participated in this study. The findings show that the main factor on the tendency of misconduct is lack of parental control and peer influence. Majority of the offenders also never attended the PLKN which can be associated with lack of awareness on the implication of delinquent behavior. The adoption of moral values in the family and educational institutions and the community are the main recommendations addressed to ensure youths are not involved in this issue.
\end{abstract}

Keywords: delinquent behavior, youthful offender, Community Service Order

\section{Introduction}

Numerous corrective actions programmes have been implemented through several government policies and initiatives to overcome social delinquent behavior among youth. Despite these efforts, the number of cases reported on social problems are still alarming. Drug addiction, teen pregnancy, bullies, snatch gambling and many more are among never ending issues faced by the society.

This study will contribute to the latest findings on the factors of delinquent behavior among youth by focusing on the Community Service Order (CSO) Programme trainees. Not to deny that, a lot of studies have been done on the similar field, but the novelty of this article is by looking at the real factors faced by the youthful offenders in Malaysia in recent years and how it relates to PLKN programme.

Since 2013, the cases reported for youthful offenders and new cases for CSO programme participation have decreased subsequently. But the trend has shown a slow drop with $3 \%-4 \%$ decline every year. Thus, this requires serious attention from every sector in the country. For record, CSO programme is one of the state interventions to curb this issue as well as the 
method to teach and give lessons to the youthful offenders on the consequences of committing any offences. However, whatever interventions proposed will not be effective and cannot be the sole solution for this problem without understanding the root of causes to this issue.

\section{Method}

\subsection{CSO Programme in Malaysia}

CSO programme is one of the initiatives to improve social problems among youth in many countries like in the United States of America and Singapore (Othman, 2014). In Malaysia, it was established under the Department of Social Welfare (JKM), Ministry of Women, Family and Community Development on February 1, 2007 with a specific division called Division of Community Service Order. This is as a result of the decision by the Special Committee of Parliament Options. The legal reference for the programme is Criminal Procedure Code (Amendment) Act 2006 [Act A1274] and the Penal Code (Amendment) Act 2006 [Act A1273]. Under Section 293. (1) of the stipulated Act, it stated that:

"When any youthful offender is convicted before any Criminal Court of any offence punishable by fine or imprisonment, the Court may, instead of awarding any term of imprisonment in default of payment of the fine or passing a sentence of imprisonment - (e) (1) To make an order requiring the offender to perform community service, not exceeding 240 hours in aggregate, of such nature and at such time and place and subject to such conditions as may be specified by the court;

Youthful offender can be defined as a person convicted of an offence punishable by fine or imprisonment who is of or above the age of eighteen and below the age of twenty-one, as prescribed under Section (2)(1) Criminal Procedure Code. Based from Table 1, it shows the slow decline in the cases reported for youth offenders from 2013 to 2018 . This data should not be underestimated hence need to be addressed seriously to maintain continuous reduction of the cases.

Table 1. Cases of youth offenders by year

\begin{tabular}{cccc}
\hline Year & $\begin{array}{c}\text { Total number of } \\
\text { youth offenders }\end{array}$ & $\begin{array}{c}\text { Total number of } \\
\text { new cases of CSO }\end{array}$ & $\begin{array}{c}\text { Cases of CSO are still } \\
\text { handled by JKM }\end{array}$ \\
\hline 2018 & 1279 & na* & 771 \\
2017 & 1450 & na* & 926 \\
2016 & 1582 & na* & 870 \\
2015 & 1446 & na* & 934 \\
2014 & 1627 & 810 & na* \\
2013 & 1451 & 387 & na* $^{*}$ \\
\hline \multicolumn{3}{r}{ Sources: JKM website } \\
& & *na : data not available &
\end{tabular}

There are few types of offences categorized as a delinquent behavior which may result in fine, imprisonment, and community service order. Table 2 has listed down the types of offences for various years. 
Table 2. Cases of youthful offenders by types of offence and year

\begin{tabular}{lcccccc}
\hline Types of offence & $\mathbf{2 0 1 8}$ & $\mathbf{2 0 1 7}$ & $\mathbf{2 0 1 6}$ & $\mathbf{2 0 1 5}$ & $\mathbf{2 0 1 4}$ & $\mathbf{2 0 1 3}$ \\
\hline Property & 474 & 511 & 544 & 578 & 645 & 630 \\
Drugs & 256 & 450 & 367 & 371 & 359 & 346 \\
People-related & 93 & 115 & 238 & 126 & 145 & 94 \\
Traffic & 260 & 149 & 167 & 93 & 151 & 138 \\
Weapon / Fire-arm & 30 & 23 & 65 & 51 & 64 & 47 \\
Minor offence act & 4 & 5 & 8 & 8 & 8 & 9 \\
Gamble & 24 & 3 & 11 & 23 & 10 & 16 \\
Infringement of supervision term & 1 & 1 & 6 & 8 & 13 & 3 \\
PLKN refuse & 0 & 0 & 1 & 5 & 9 & 1 \\
Others & 137 & 193 & 175 & 183 & 223 & 167 \\
Total & $\mathbf{1 2 7 9}$ & $\mathbf{1 4 5 0}$ & $\mathbf{1 5 8 2}$ & $\mathbf{1 4 4 6}$ & $\mathbf{1 6 2 7}$ & $\mathbf{1 4 5 1}$ \\
\hline \multicolumn{7}{l}{} \\
& Sources: JKM website & & & \\
& *na: data not available & & &
\end{tabular}

By referring to the table above, offences related to property (robbery, snatch, theft) and drugs have shown the highest rate compared to others. It is also important to learn that the cases for traffic, gamble, weapon and fire-arm, show an increase in 2018 despite the decline in previous years.

The same pattern of decline followed in the total numbers of new cases of CSO trainees (see table 1). However, it is quite difficult to analyze the trend with the absence of data in 2013, and 2014. According to the Department of Social Welfare Statistic Yearbook 2018, 771 cases (trainees) of CSO are still handled by the JKM which represents $60 \%$ from the total number of youth offenders. These trainees are required to undergo the community service, which prescribed as "... any work, service or course of instruction for the betterment of the public at large and includes, any work performed which involves payment to the prison or local authority" under the subparagraph 293(1)(e)(ii). Even though CSO programme is perceived an alternative for punishment [1], but the main objective of this CSO programme is to prevent young offenders from repeating criminal offences in the future. This is also to bring them into society through three elements: penalties, recovery and conversion.

\subsection{Delinquent Behavior: Issues and Challenges}

\section{a. Delinquent behavior among Youth}

Currently, there is a disturbing increment of youth involvement in misconduct and criminal activities in urban and suburban regions of Malaysia based on annual's JKM Statistical Report. It has been a major concern among the public, particularly the policy makers, local authorities etc. According to Haslinda, delinquency is specifically used to describe anti-social behaviours that are considered unlawful in Malaysia (e.g. using drugs, damaging public properties, hitting or physical assaulting others, driving without a license, carrying weapon, drinking alcohol, engaging in premarital sex, etc.) [2]. Meanwhile youth or delinquency refers to the participation in illegal behaviour by young people under the statutory age of majority which in most countries is 19 years old [3]. There are many factors identified that are linked to delinquent behaviour among teenagers such as; the influence of peer group, family socioeconomic background and religion which have been researched by Hirschi [4], Mohideen et.al., [5], Ihsana \& Pudjo [6], Shahabudin [7], Pit Wan Pung et.al., [8]and many others. 


\section{b. Peer Group Influence}

Peer delinquency is one of the major contributing components to social abnormality among young people and adolescents. The inclination to take a stab at something new and incitement from the associate gathering regularly result in young people being included in criminal exercises [9]. Thus, they are likely to act and behave similarly like the other members in their groups as proposed by previous research by Hirschi [4] and Asmah [10].

As the Malaysian adolescents face different life difficulties and experience trouble, they are at danger of getting to be distinctly disappointed and unhappy young people and may get to be involved in pessimistic exercises, for example, gangsterism, bullying, drug abuse and sexual wrongdoing [7]. In most cases, they do not do it alone. They are being accompanied by their friends who have the same preferences.

When the role of the deviant peer group greatly influences them, the youths who encounter peer misconduct may behave in an aggressive way. Furthermore, peers become important for young people in terms of socializing with the world outside home. This is because they have a tendency to behave similar to their companions with the end goal is to gain acceptance and appreciation from them [8]. Obviously, this is something that is to be expected as they spend more time with their friends rather than with their families. The same findings were also found in a study by Ihsana \& Pudjo [6] about the role of delinquent peer groups in juvenile delinquency in Indonesia.

\section{c. Family Background}

There are lists of studies that have addressed the impacts of socio-economic status of family on delinquent behaviour. The parents' background such as the type of occupation, income and educational level seem to be the influential factors that determine the socioeconomic status of a family [11]. For instance, when the parents could not afford to provide sufficient necessities due to the low income, the children might find other alternatives of getting what they want.

Related to that, youngsters who are at danger becoming delinquent frequently live in troublesome conditions. Achievement in school depends greatly on whether guardians have the ability to give their children money to purchase books and other necessities to pay for studies. Young people from low-wage families frequently feel excluded. Therefore, to increase their self-esteem and enhance their status they may join a juvenile reprobate gathering [12]. Thus, the group will be the platform for them to fulfil their goals. They will look for some additional money by any means regardless of whether it is legal or not, so that they could enjoy their life [13]. Indirectly it shows how poverty could affect the behaviour of the young people.

Moreover, Hoeve [14] also highlights that parents are often blamed for the delinquent behaviour of their children. Whatever they do, the impacts are always on their children. If they fail to inculcate positive values towards them, there is a tendency they will become rebellious and may act in an aggressive way. On the other hand, lacking parental direction to teach youngsters on the correct way of doing things is also one of the influential factors that lead to juvenile delinquency [15].

In addition, most research has shown that the strongest predictor of juvenile delinquency was related to poor parental supervision. These include factors such as advanced paternal age, maternal employment and single parenthood which lead them or make them more prone for juvenile delinquency or delinquent behaviour [16]. Apart from that, according to Hoeve [14], children in different family structures also experience many forms of monitoring, supervision, involvement, and attachment they receive from their parents. It was found that, generally studies found children who live in cohabiting households are much more likely to 
participate in juvenile delinquency compared to those in two-biological-parent households. Besides, the presence or absence of a father figure in the household become another important factor to delinquency [17].

\section{d. Media Influence}

Media, the internet in particular, is said to significantly contribute to the delinquent behaviour of the young people. As the role of technology is increasingly becoming important nowadays, the presence of unfiltered online information can get to be one of the essential contributors to social problems. Youth make their own world utilizing these technological devices for good and bad purposes. Youngsters can be easily controlled online by immoral people with their own plan to impact or "indoctrinate" them to wrongdoings [18]. The eagerness to explore and learn new things displayed on the internet definitely leave the youngsters to be exposed to the risk of aggressive behaviors. Unsuitable images and videos related to crime activities could simply influence the thinking of these young people. Similarly, television is also said to develop aggressive behaviour of the young viewers'. Physical and verbal violence shows on television seem to encourage the youngsters to imitate such behaviours [19]. Repeated and consistent exposure could definitely cause changes in their behaviors.

\section{e. Self-Control}

Self-control is another factor identified to influence the behaviours of the young people. Previous research found that self-control was positively linked to aggression behaviour of the adolescents. Low level of self-control could influence them to behave impulsively and could lead to misconduct [8]. Adolescents who were low in overall self-control were found to be more likely to be involved in nonviolent delinquency, with risk-seeking and self-centeredness being the only two specific low self-control indicators to yield significant influences on their nonviolent delinquency [20]. Furthermore, the lack of guidance during these years would definitely cause them to misbehave and there is a high tendency to engage in unhealthy activities. It is also found that juveniles with lower levels of self-control may be more likely to engage in delinquency and interact with delinquent peers, which, in turn, may increase the youth's risk of victimization [21]. They tend to be more selective in choosing their companions and likely to find friends whom possess the same characteristics. Thus, this deviant peer association could definitely lead to aggressive behaviour among them.

\section{f. Theories Govern Delinquent Behaviour}

As has been mentioned by many scholars and previous studies, antisocial behaviour is related to the syndrome of deviant behaviour where the people frequently act against the standard values, norms as well as social rule. Furthermore, those who are more prone to antisocial behaviours would not feel guilty for their actions in which an individual has a relationship with different attitudes to being involved with negative activities. Understanding of delinquent behaviour can also be achieved through referring to several theories. For example, as reported by many studies specifically according to Social Learning Theory, it is shown that peers are a powerful source of influence in adolescence [22], [23].

Besides, another theory that was also discussed about delinquency study is known as Theory of Social Disorganization. Previously, this theory was developed by Shaw and McKay [24] which demonstrates that neighbourhood structural characteristics correlated with delinquency rates. According to this theory, due to the social disorganization of their neighbourhood it leads toward weakening the authority of local social institutions. Furthermore, this theory also stated that the inability of local social institutions to control resident behaviour especially the young age group is because of the breakdown of informal control within the society. Moreover, the issue of lack of control will raise many problems 
such as drug abuse, high levels of school dropout, single parent families, unemployment and many more. It is also highlighted that besides the neighbourhood, another important agent of socialization are schools [25].

In understanding more about delinquent behaviours, besides Social Disorganization Theory as well as Social Learning Theory, the works of Hirschi and Jessor \& Jessor also need to be taken into an account. According to Hirschi's Social Control Model, the most important element in preventing adolescents from committing deviant acts are bonds or attachments. Based on the study, he found that adolescents with low levels of conformity are easier to be influenced by negative acts with the assumption that people with the element of weak "social bond" to the society would have high chances in engaging in delinquent behaviour [26]. Therefore, it is also stated that the chances of engaging with the negative behaviour would be decreased if an individual has a close relationship with his family, friends as well as to the community (e.g. religious institutions). In addition, once an individual can react with his environment positively, the individual will automatically be helped to move away from negative consequences. The finding from Hirschi's Social Control Model also can be seen as in line with another theory which is known as Social Ecological Theory by Bronfenbrenner. $\mathrm{He}$ indicates that human developments have a close relationship with the growing individual and their environment.

Furthermore, besides all the above-mentioned theories, there is another theory that is also valuable in understanding the adolescent problem behaviours which is related to risk and protective factors [27]. Referring to this finding, he stated that the risk factors are normally associated with elements of "increase" whereby "decreasing" likelihood of engaging in problem behaviour are more on the protective factors. All these can be related to the study on family structure and parental involvement whereby they take into an account that lack of family management as well as poor family monitoring such as minimal parental supervision, also cause the occurrence of social problems among adolescents [28].

This paper investigates the main factors of the offences among youthful offenders in the Community Service Order Programme, supervised under the JKM. This study used a quantitative method with a cross- sectional design. The sampling technique adopted for this survey is convenience sampling. The sample of 90 questionnaires was distributed to all the trainees that joined the event of "Program Sirih Pulang ke Gagang" organized by the JKM and only 78 safely returned and analyzed. This number met the minimum sample size required by Krejcie \& Morgan theory on sampling. The questionnaire was developed through a process that entailed a brainstorming session, followed by review on the literature in order to get some important points for this study. A small-scale pilot run was conducted on the drafted questionnaire to sharpen the language and to ensure that smooth rapport could be built between the respondent and the researcher.

Afterward, a large-scale quantitative survey was conducted with this questionnaire. In order to study the perception of Community Service Order Programme trainees towards delinquent behavior in Malaysia, the questionnaire consists of 4 sections namely, demographic, respondents experience on social issues, respondents perception towards the causes of social issues, and the last part is about the recommendations to improve the Community Service Order Programme itself. The response to questions is measured by 5point Likert scale. The data was captured directly in SPSS v26 format and frequency tables on the response were tabulated to scan for errors in data entry or coding before it proceeded to further analysis. The analysis began with scanning for all the data and descriptive analysis done for demographic. Anova analysis also used to measure the relationship between few 
variables. This simple but effective test is a good start to scan for relationships between variables.

\section{Result And Discussion}

Table 3. Respondents' profile

\begin{tabular}{|c|c|c|}
\hline Respondents' Profile & Answer & Response (\%) \\
\hline \multirow[t]{7}{*}{ Education Level } & Never been to school / dropout & $4(5.1 \%)$ \\
\hline & UPSR & $5(6.3 \%)$ \\
\hline & PMR & $16(20.3 \%)$ \\
\hline & SPM/SPMV & $29(36.7 \%)$ \\
\hline & STPM/Diploma & $6(7.6 \%)$ \\
\hline & Certificate & $5(6.3 \%)$ \\
\hline & Bachelor Degree & $14(17.7 \%)$ \\
\hline \multirow[t]{4}{*}{ Where do you live } & Urban & $38(48.1 \%)$ \\
\hline & Small town & $16(20.2 \%)$ \\
\hline & Village & $24(30.4 \%)$ \\
\hline & Estate / FELDA & $1(1.3 \%)$ \\
\hline \multirow[t]{3}{*}{ Your emotional State } & Always in control & $68(86.1 \%)$ \\
\hline & Easily freak out / bad temper & $9(11.4 \%)$ \\
\hline & Always dissatisfied / revenge / stressful & $2(2.5 \%)$ \\
\hline Have you attended the & Yes & $25(31.7 \%)$ \\
\hline PLKN programme? & No & $54(68.3 \%)$ \\
\hline
\end{tabular}

According to Table 3, it indicates the profile of respondents in this study. Majority of them have SPM/SPMV education background which means they have fulfilled the secondary schooling completion and coming from urban area which more prone to expose with the social issues. Most of them also claimed their emotion are always in control, means they are not suffered from any stressful condition. More than half of the respondents also responded that they never attended the PLKN programme organized by the government.

From the survey, the result of frequencies analysis towards the causes of delinquent behavior issues shows that there is a significant relationship between all the four variables with the delinquent behavior issues in Malaysia. The causes of delinquent behavior among youth highlighted in this study are lack of parental control, peers influence, self-decision, and also internet/ mass media. Based on the findings, it indicates that lack of parental control became the most influential factor that has caused the youth involvement in social problems, followed by peer influence, internet/mass media and self-decision. Thus, this finding supported the previous studies from Ali. K [13], Haslinda [2], Pit-Wan Pung [8] and Shahabudin [7]. The future direction on policy implementation to solve this issue must prioritize the role of parents in family institution.

Table 4. Mean rank for factors that caused delinquent behavior

\begin{tabular}{lcc}
\hline Factor & Mean & Ranking \\
\hline Lack of parental control & 4.0253 & 1 \\
Peer influence & 2.9072 & 2 \\
Internet \& mass media & 2.7595 & 3 \\
Self-decision & 2.5759 & 4 \\
\hline
\end{tabular}


Another important thing that we want to highlight in this study is about the relationship of respondents' emotion level with the reasons why they involve in the social problems, whether the Community Service Training Programme (PLKN) have relationship with the reasons of their involvement in the social problems, and also the implications since they involved in this social problems. The Anova testing were tested to determine the result of all the questions above and the finding as below:

Table 5. ANOVA Testing related to the involvement in PLKN Program

\begin{tabular}{l|l|c}
\hline No. & \multicolumn{1}{|c}{ Variables } & Alpha Value \\
\hline 1. & Emotional state of respondents \& causes of delinquent behavior & 0.022 \\
\hline 2. & $\begin{array}{l}\text { Does respondents has attended PLKN \& causes of delinquent } \\
\text { behavior }\end{array}$ & 0.010 \\
\hline 3. & $\begin{array}{l}\text { Does respondents has attended PLKN \& Implication received } \\
\text { since the involvement in delinquent behavior }\end{array}$ & 0.008 \\
\hline
\end{tabular}

Based on the table above (refer Table 5), we can see that all of the variables tested have significant relationship to each other. For the first question, what we can conclude from the finding is that most of the respondents $(86.1 \%)$ admit that their emotion is always in good condition (controlled) and they know they did something that was considered wrong.

Interestingly, from the finding above, more than half of the respondents $(67.1 \%)$ did not join PLKN Program. The absence of respondents to this programme can be relate to that lack of awareness among them towards the impact of social problems prepared by the modules during PLKN which resulted to the involvement in social problems. Thus, it is believe that, PLKN programme also may influence the behavior of youth through the content of the modules. The study from Ismail, Abdullah \& Mohd Noor [29] has proven that implementation of the PLKN is seen as a key mechanism to address the problems among the youth, enhance their self-esteem and thus bind their allegiance to the country. However, this programme was dissolved on 13 August 2018.

\section{Conclusion}

The reflection from the findings of this study has shown that, the roles of parents are very important in addressing the issue. Close supervision and monitoring are consistently needed from time to time. Positive parenting approaches must be adopted, parents need to know the right parenting skills to be applied as stipulated under Principle 2 of the National Family Policy [30]. Lack of attention, love and guidance from parents would definitely lead the children to produce delinquent behaviour. An effective communication between parents and their children is also required to ensure the understanding among them. Children should be given opportunities to voice out and to suggest matters related to their lives. This is because a lack of communication could cause them to be upset, unloved and rejected. It is the time to empower the National Family Policy through the holistic direction for family wellbeing by strengthening the family institution.

At the same time, the need to develop effective mechanisms at schools is highly important as the peer group pressure and influence also contributes to delinquent behaviour among youth. It is important for schools to take necessary steps as a prevention rather than to focus on the treatment. Teachers in particular, need to be very sensitive in observing the behavioural change of the students. They are in the right position to identify potential students that are 
likely to deal with emotional or physical disturbance. Counselling sessions and discipline programs at schools are some of the preventive mechanisms that can be taken into consideration in order to address the problem of juvenile delinquency.

Furthermore, as the role of technology is increasingly becoming important, the media is seen as an essential weapon in shaping the behaviour of the children. Media aggression could simply influence them to act the same as what is being displayed on the television/internet as they are in a state of inability to differentiate what is real and what is not. Even though the government has regulated the Communications and Multimedia Act 1998 to, but the individuals are responsible for their own action to choose whatever best for them through internet and mass media. Thus, parents play a very essential role to provide sufficient information to their children pertaining to the media content and the negative implications of it. The National Service Training Program (PLKN) should be reintroduced by the government as one of the important approaches to educate youth on citizen's responsibility towards the nation. This three-month program was first introduced in 2003 with the aim to promote the relationship of different races and ethnic communities, to nurture positive characteristics among the younger generation and to develop a patriotic generation that is loyal to the government. Throughout this program, youth are also exposed to awareness of the implication if they are known as youthful offenders. Even though this programme has been criticized and politicized by many parties, it is always important to look from the positive side. In a nutshell, the concerted effort to address the issue on delinquent behavior is very prominent, since the contributing factors are from various aspects. The multisectoral approach from public and private agencies as well civil society are equally important to solve this problem through the relevant policies and programmes. Ultimately, this is hoped to achieve the sustainable development goals for the social wellbeing.

\section{References}

[1] Anita Abdul Rahim, T. N. Community Service as an Alternative Punishment: The Extent of its Application. International Journal of Education and Research, Vol.1 No.7, 1-8. (2013).

[2] Haslinda Abdullah, A. O. Aggressive and Delinquent Behavior among High Risk Youth in Malaysia. Asian Social Science and Education. (2015).

[3] Siegel, L. \&. Juvenile Delinquency. Belmont, CA: Wadsworth, Cengage Learning (2011).

[4] Hirschi, T. Causes of Delinquency. Routledge. (2017).

[5] Mohideen, R.S., Rahman, F.A., Shazali, N.M., Zayid, Z., \& Fauzi, N.F. Public Perception on the Factors that Contribute to Juvenile Delinquency: A Case Study at Urban Transformation Centre (UTC) Melaka. Regional Conference on Science, Technology and Social Sciences, (2016). 591-600. doi 10.1007/978-981-10-1458-1.

[6] I EL Khuluqo and P. Sumedi. Overcoming Juvenile Delinquency among High School Students through the Implementation of a Curriculum for Commendable Morality. Journal of Education and Social Sciences, Vol. 5, (October) ISSN 2289-1552. (2016)

[7] Shahabudin Hashim, S. K. A Review of Literature on At-Risk Adolescent Students in Malaysia: Needing an Academic Resilience Model. SHS Web of Conferences. United Kingdom: EDP Sciences. (2016).

[8] Pit-Wan Pung, S. N. Low Self-Control, Peer Delinquency and Aggression among Adolescents in Malaysia. Asian Social Science, Vol 11, No 21. (2015).

[9] Kassim, A. W. Juveniles on Remand: Trends and Practices in Malaysia. Retrieved from United Nation Malaysia and Far East Institute: (2006). http://www.unafei.or.jp/english/pdf/RS_No68/No68_17PA_Kassim.pdf. 
[10] Asmah. The Community Service Order (CSO) in Malaysia: An Exploration of the Perceptions And Experiences of the Youthful Offenders and Supervisors. (Unpublished doctoral thesis). University of Salford, Salford, UK. (2013).

[11] Ling, M. O. The Relationship between Family Socioeconomic Status and Lifestyle among Youth in Hong Kong. Hong Kong: City University of Hong Kong. (2013).

[12] Nations, U. Juvenile Delinquency. Retrieved from World Youth Report: (2003). http://www.un.org/esa/socdev/unyin/documents/ch07.pdf

[13] Ali, K. Constructing Juvenile Delinquency: An Analysis of News Media Coverage and Government Response to Youth Crime in Malaysia. Australia: Institutional Repository of UNSW Australia. (2012).

[14] Hoeve, M., Dubas, J.S., Eichelsheim, V.I., van der Laan, P.H., Smeenk, W., \& Gerris, J.R.M. The Relationship between Parenting and Delinquency: A Meta-Analysis. Abnormal Child Psychology, 37, 749-775. (2009).

[15] Vijaindren., A. Raising Wave of Juvenile Crime. Retrieved from New Straits Times: http://www.nst.com.my/news/2015/09/rising-wave-juvenile-crime. (2014, December 14).

[16] Rathinabalan I, Naaraayan SA. Effect of Family Factors on Juvenile Delinquency. International Journal on Contemporary Pediatric, (2017);4:2079-82.

[17] Kierkus, C.A., Johnson, B.R., \& Hewitt, J.D. Cohabitating, Family and Community Stressors, Selection, and Juvenile Delinquency. Criminal Justice Review, 35(4), 393-411. (2010).

[18] Muzammil, B. Young And Certainly Getting Dangerous: The Rise of Juvenile Criminals. Retrieved from Malaysian Digest (2014, October 16).: $\mathrm{http}: / /$ www.malaysiandigest.com/features/523273-young-and-certainly-getting-dangerous-therise-of-juvenile-criminals.html

[19] Mudassar Abdullah, N. A. Exposure to Television Crime Shows and Crime Learning Behaviours of Adolescents: A Case of Pakistani Juvenile Delinquents. International Soft Science Conference. Langkawi Island, Malaysia: Universiti Utara Malaysia. (2016).

[20] Chui, W. H., and H. C. O, Chan. The Influence of Low Self-Control on Violent and Nonviolent Delinquencies: A Study of Male Adolescents from Two Chinese Societies. The Journal of Forensic Psychiatry \& Psychology, Vol. 28, No. 5, 599-619. (2017).

[21] Cho, S. \& J. Wooldredge. Direct and Indirect Effects of Low Self-Control on the Personal Victimization of South Korean Youth. Journal of Youth Studies. Vol. 21, No. 7, 958982. (2018).

[22] Brechwald, W. A., \& Prinstein, M. J. Beyond homophily: A Decade of Advances in Understanding Peer Influence Processes. Journal of Research on Adolescence, 21, 166-179. (2011). doi:10.1111/j.1532-7795.2010.00721.x.

[23] Veenstra, R., Dijkstra, J. K., Steglich, C., \& Van Zalk, M. H. W. Network-behavior dynamics. Journal of Research on Adolescence, 23, 399-412. (2013). doi:10.1111/jora. 12070.

[24] Shaw, Clifford Robe, and Henry Donald McKay. "Juvenile delinquency and urban areas." (1942).

[25] DiPietro, S. M., Slocum, L. A., \& Esbensen, F. A. School Climate and Violence: Does Immigrant Status Matter? Youth Violence and Juvenile Justice. Advance Online Publication. (2014). doi:1541204014547589.

[26] Hirschi, T. Causes of Delinquency. Berkeley, Calif., U. California Press. (1969).

[27] Jessor, R, Van Den Bos, J., Vanderry, J., Costa, F. M., \& Turbin, M. S Protective factors in Adolescent Problem Behavior: Moderator Effects and Developmental Change. Developmental Psychology, 31(6). 923-933. (1995).

[28] Fagan, A. A., Van Horn, M. L., Antaramian, S., \& Hawkins, J. D. How do Families Matter? Age and Gender Differences in Family Influences on Delinquency and Drug Use. Youth Violence and Juvenile Justice, 9, 150-170. (2011). doi:10.1177/1541204010377748.

[29] Ismail, Mohd Mahadee, Mohd Syariefuddin Abdullah, and Mansor Mohd Noor. "Signifikan Implementasi Program Latihan Khidmat Negara (PLKN) di Malaysia." Jurnal Kinabalu (2014).

[30] National Population and Family Development Board (nd). National Family Policy Malaysia. Kuala Lumpur. 